\title{
Postcolonial Network Analysis of Joseph Conrad's Heart of Darkness
}

\author{
Lestari Manggong ${ }^{1}$, Mohamad Noor Rizal ${ }^{2}$ \\ Department of Literature and Cultural Studies Universitas Padjadjaran ${ }^{1,2}$
}

\{lestari.manggong@unpad.ac.id ${ }^{1}$, m.n.rizal@unpad.ac.id $\left.{ }^{2}\right\}$

\begin{abstract}
In the field of literary studies, Joseph Conrad's masterpiece, Heart of Darkness (1899), has been extensively researched. Following the emergence of digital humanities, new methods of analysis on the novella have also been conducted; one of which focuses on Network Text Analysis (NTA) of the work (Hunter and Smith, 2014). In reaction to this, for the contribution of recent studies in literature, this essay attempts to perform an analysis on network construct between the Company and Kurtz (the two main nodes in the network) in Heart of Darkness using two web-based network analyzers: Voyant Tools and Cytoscape. The analysis refers to, to name a few, Ferguson's (2017) observation on network in history and Jagoda's (2016) observation on network aesthetics in novels. This essay ultimately seeks to map out the network linking the two nodes and see how postcolonial view on the visualization is conducted.
\end{abstract}

Keywords: Joseph Conrad, Heart of Darkness, network analysis, the Company, postcolonial view.

\section{INTRODUCTION}

As a novella showcasing an "imperial attitude," [1], Heart of Darkness $(H o D)$ by Joseph Conrad[2] also illustrates intricate textual connectedness between Marlow, the Company, and Kurtz. In today's world of digital humanities, this connectedness can be translated into chains of networking, and prompts new methods of analysis on the novella. As a result, a Network Text Analysis (NTA) of the work was conducted by Hunter and Smith (2014), where it argues Stubbs' (2005) assertion that a recurring and dominant theme in $H o D$ is the "unreliable and distorted knowledge" of Marlow's [3] ${ }^{2}$. Hunter and Smith (2014) contest this assertion using their own method of text network analysis ${ }^{3}$ which reveals that their text network approach "displays specific chains or links among words and groups of words in a way that traditional frequency-based content analysis and stylistics can not [sic]" that further "allows not just the representation of those relationships, but also their quantification along such dimensions as

\footnotetext{
${ }^{1}$ By this, it means that "[o]n the one hand, the narrator Marlow acknowledges the tragic predicament of all speech ... [and] yet still manages to convey the enormous power of Kurtz's African experience through his own overmastering narrative of his voyage into the African interior toward Kurtz" [1].

${ }^{2}$ This is the result of his corpus stylistic, content-analytic examination of $H o D$.

3 Theirs uses the morpho-etymological approach, meaning that "the network is constructed from morphological and etymological relationships among words in the text" [3].
} 
strength, connectedness, and distance" [3]. In support of this view, this essay focuses on the connectedness between Marlow, the Company, and Kurtz within postcolonial studies, by particularly analyzing the network construct between the Company and Kurtz (the two main nodes in the network). In doing so, the analysis includes discussions on the mapping of network among those nodes, retrieved with the use of two web-based network analyzers: Voyant Tools [4] and Cytoscape [5].

The initial idea of this essay is highly influenced by Ferguson's (2017) observation on network in history. Parallel to Ferguson's approach, this essay observes the textual network in $H o D$ that is built through the nodes' connectedness. An example of visualisation of network in Shakespeare's Hamlet may look like this:

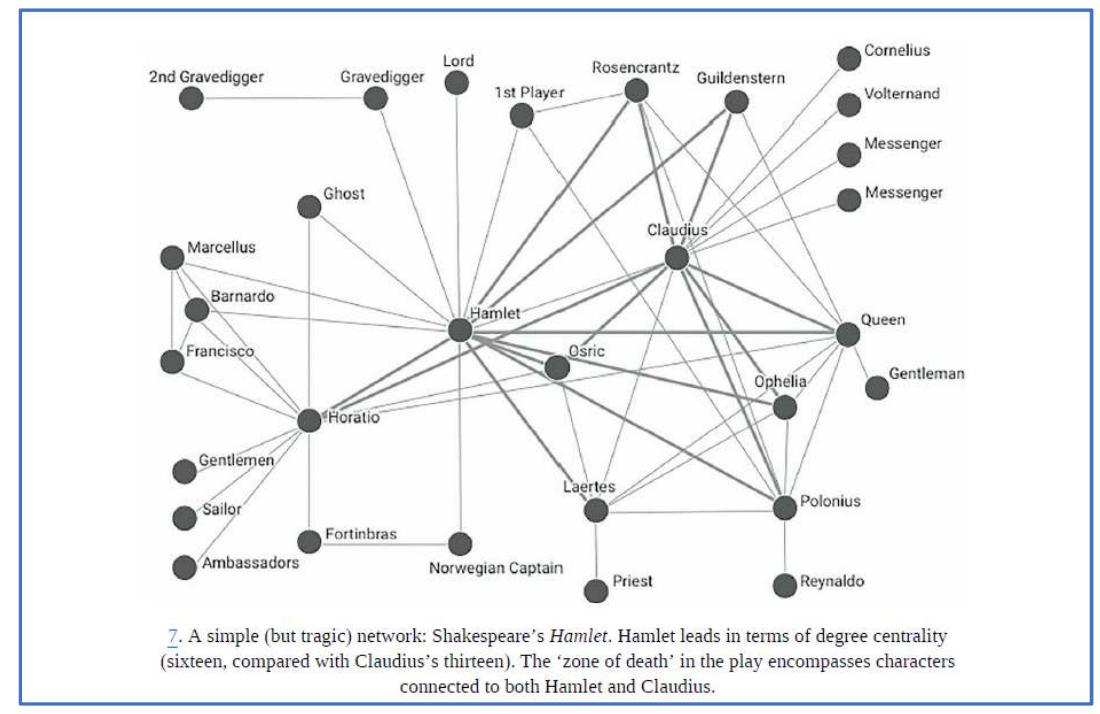

Figure 1. Network in Hamlet [6]

The network in Figure 1 is made manually by looking closely at the relations between the characters in the play. As argued by Hunter and Smith (2014), corpus stylistic, contentanalytic examination, frequency-based content analysis and stylistics is not enough to accommodate an analysis on connectedness that shows the structure of textual network between characters and places [3]. The structure of textual network in $H o D$ is then associated with the work's novelistic form, since "network visualizations offer a stable representation or a map of elements configured as nodes and links, [whereas] the novel makes possible processes of mapping networks across space and time" [7]. This way, the discussion in this essay is of two folds: mapping out the network structure and showing how postcolonial view on the visualization is conducted.

\section{Methodology}

In general, a 'network' is defined as "a structure composed of links and nodes" [7]. The term refers to "the informal concept describing an object composed of elements and interactions or connections between these elements", like the Internet, which is "a network 
composed of nodes (routers, hosts) and connections between these nodes (e.g. fiber cables)" [8]. Network analysis, in its broader sense, can be applied in biology, computer science, economy, physics, or in ordinary life [9]. Network analysis in ordinary life gives result to the practice of sociological network, which stems into social network studies. In the analysis, this essay adapts two designs of social network studies namely "whole-network" or "egocentric" designs; "[w] hole-network studies examine sets of interrelated objects or actors that are regarded for analytical purposes as bounded social collectives, although in practice network boundaries are often permeable and/or ambiguous, [whereas] [e]gocentric studies focus on a focal actor or object and the relationships in its locality" [10].

The distinction between structures identified as whole-network and ogecentric designs is seen upon analyzing the mapping of network in $H o D$ which results from the use of Voyant Tools and Cytoscape. Voyant Tools are used to reveal the statistics of the words in the studied text. In Voyant Tools, there are several tools that can show specific result. This essay uses TermsBerry tool to find the words around the selected key words. ${ }^{4}$ The result from TermBerry process in Voyant Tools is converted to a table form containing the data of key words and their related words. After retrieving the data, Cytoscape was utilized to visualise the data into a network relation. The visualisation will then be discussed within the field of postcolonial studies, focusing on the interconnectedness between Marlow, the Company, and Kurtz, by comparing the result of automated surface reading of network using the two tools with the result of manual close reading of the novella.

\section{Findings and Discussion}

\subsection{Findings}

This section provides the results of NTA, which is different from the ones conducted by Stubbs (2005) and Hunter and Smith (2014), using Voyant Tools and Cytoscape . The findings in this section are the results of the connectedness/network seen between key words using the two aforementioned textual analysis tools. In revealing the statistics of the words in the studied text, TermsBerry tool was used to find the words around the selected key words. The result from TermBerry process in Voyant Tools is converted to a table form containing the data of key words and their related words as follows:

Table 1 The result of TermBerry process

\begin{tabular}{|l|l|}
\hline \multicolumn{1}{|c|}{ Key word } & \multicolumn{1}{c|}{ Related Word } \\
\hline Kurtz & Talk \\
\hline Kurtz & Began \\
\hline Kurtz & Went \\
\hline Kurtz & Got \\
\hline Kurtz & Wanted \\
\hline Kurtz & Wanted \\
\hline Kurtz & Heard \\
\hline Kurtz & Course \\
\hline Kurtz & Think \\
\hline Kurtz & Say \\
\hline Kurtz & Away \\
\hline
\end{tabular}

\begin{tabular}{|l|l|}
\hline \multicolumn{1}{|c|}{ Key word } & \multicolumn{1}{c|}{ Related Word } \\
\hline change & Men \\
\hline change & Man \\
\hline white man & Saw \\
\hline manager & asked \\
\hline manager & stood \\
\hline manager & Saw \\
\hline manager & Right \\
\hline manager & looked \\
\hline manager & Came \\
\hline manager & Said \\
\hline manager & looking \\
\hline
\end{tabular}

\footnotetext{
${ }^{4}$ Source: https://voyant-tools.org/docs/\#!/guide/termsberry Accessed April 12, 2019.
} 


\begin{tabular}{|l|l|}
\hline Kurtz & Said \\
\hline Kurtz & Said \\
\hline Kurtz & Said \\
\hline Kurtz & Man \\
\hline Kurtz & Come \\
\hline Kurtz & Long \\
\hline Kurtz & Just \\
\hline Kurtz & Thought \\
\hline Kurtz & Thought \\
\hline Kurtz & Suddenly \\
\hline Company & Station \\
\hline Company & Said \\
\hline Company & Man \\
\hline marlo* & Face \\
\hline marlo* & Began \\
\hline marlo* & Dark \\
\hline marlo* & Just \\
\hline marlo* & Suddenly \\
\hline Change & Came \\
\hline Change & Came \\
\hline
\end{tabular}

\begin{tabular}{|l|l|}
\hline manager & know \\
\hline manager & Time \\
\hline manager & Time \\
\hline manager & thought \\
\hline swede* & Said \\
\hline thames* & water \\
\hline station & Took \\
\hline station & Near \\
\hline station & going \\
\hline station & wanted \\
\hline station & Saw \\
\hline station & Came \\
\hline station & kurtz \\
\hline station & River \\
\hline station & Said \\
\hline station & Men \\
\hline station & ivory \\
\hline station & Left \\
\hline station & house \\
\hline & \\
\hline
\end{tabular}

After the data is retrieved, Cytoscape was used to visualize the data into a network relation. The mapping can be seen in Figure 2 below:

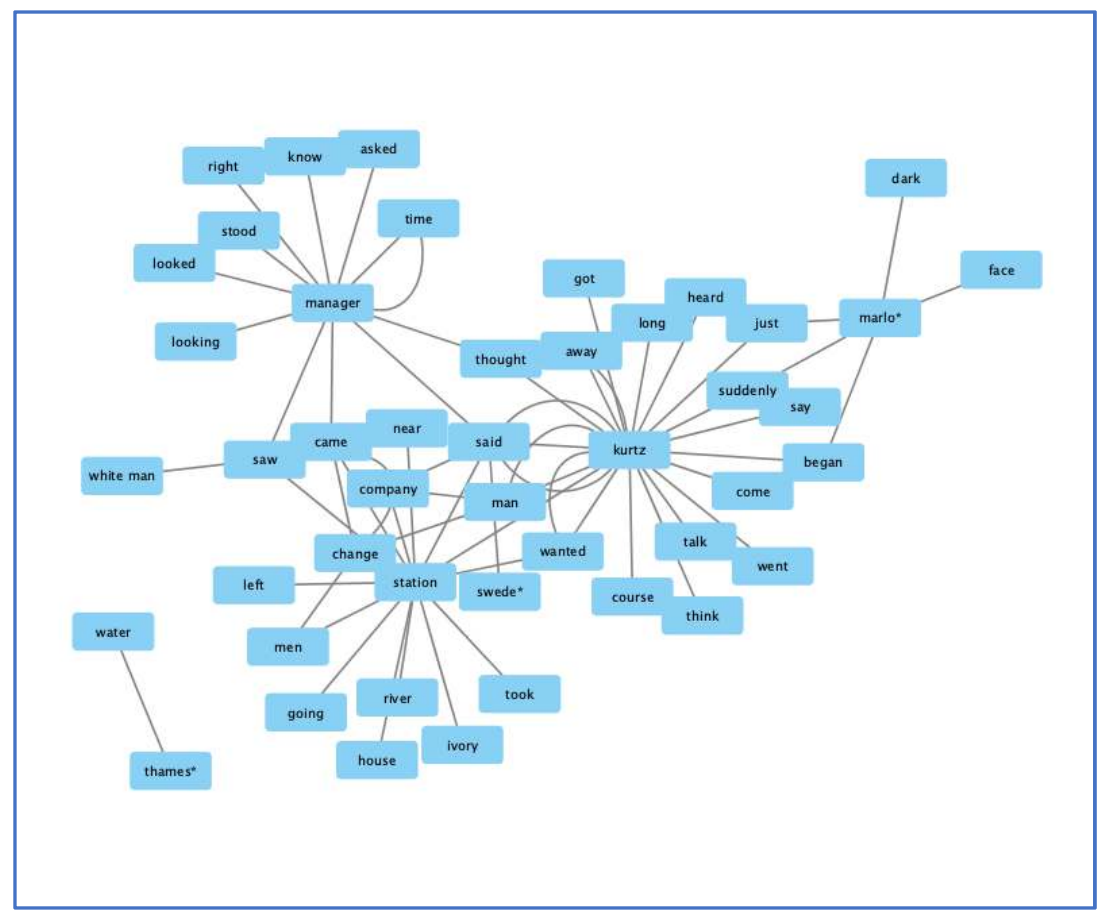

Figure 2 Network in $H o D$ from Data in Table 1 
To specify the mapping that shows only the connectedness among Marlow, the Company, and Kurtz, all verbs and adjectives and adverbs in the network scheme in Figure 1 are eliminated, resulting into the following network:

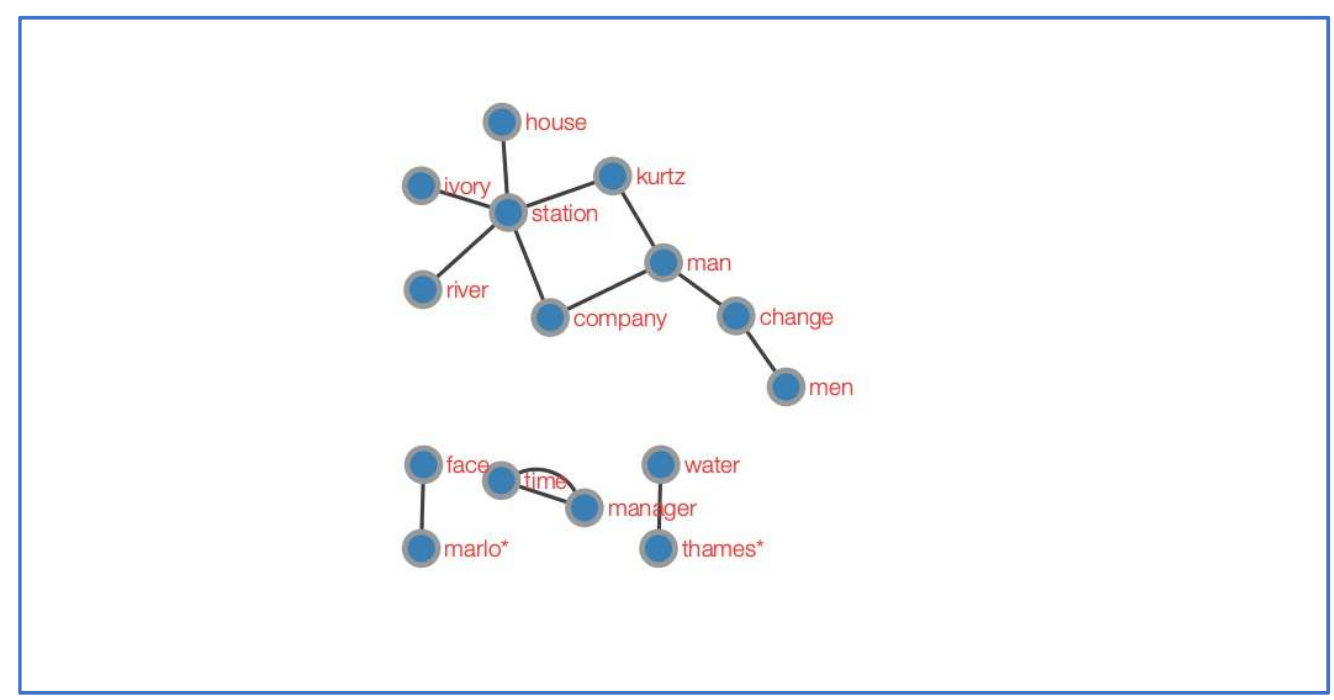

Figure 3 Network among Marlow, the Company, and Kurtz in $\mathrm{HoD}$

As can be seen in the result, Figure 3 shows that 'Station' holds the highest degree of centrality, as it has the most edges (five, to be precise). Degree of centrality is pivotal in network analysis, as "[c]entrality indices are to quantify an intuitive feeling that in most networks some vertices or edges are more central than others" [11]. It has also been "one of the most important areas of investigation in substantive studies of social networks" [12]. The mapping also shows that 'Kurtz' and 'Company' hold the second highest degree of centrality, with only two edges in each node. It comes to no surprise that 'Marlow' in the picture is placed outside the cluster formed by the entry 'Station', since in the narrative Marlow is only mentioned by the omniscient narrator approximately 10 times (mostly at the beginning of the novella, and very little at the end). Interestingly enough, in the narrative, the Company is mentioned approximately 14 times, spreading mostly at the beginning, a few in the middle, and some towards the end. We can also see in the picture that 'Kurtz' has direct connectedness with 'Station', and the same goes with 'Company'. The entry that creates connectedness between 'Kurtz' and 'Company' is 'man', which is a very generic and vastly used word in the narrative.

In response to these findings, the following section provides a discussion on how these results can be interpreted, especially in the context of postcolonial studies that focuses on the idea of "imperial attitude" seen in the novella.

\subsection{Discussion}

Perceived through whole-network studies, as "bounded social collectives" [10], Marlow, the Company and Kurtz are seen in Figure 3 in separate clusters, indicating that they are of separate circles. The main cluster at the top is the circle where the Company and Kurtz are linked, whereas the minor clusters at the bottom are small circles where each nouns are linked. Egocentric studies of Marlow as presented in Figure 3 could lead to an interpretation that Marlow is outside the big issue told and described in the main cluster. Readers of $H o D$ are 
well aware that the novella is narrated in layers of narrative. The outer layer is the omniscient narrator's narrative describing and telling the reader of Marlow's stories in Congo. The inner layer is Marlow's narrator, telling his audiences on Nellie about his experience in Congo and in meeting Kurtz there. Surface reading using the two textual analysis tools helps reveal this fact. But to comprehend an intricate narrative such as $H o D$ requires a close reading that demands the ability to identify the relationship/connectedness between the characters and the places associated with them.

A postcolonial close reading shows that "the narrative itself all share a common theme: Europeans performing acts of imperial mastery and will in (or about) Africa" [1]. In $H o D$, the empire at work is shown by the presence of white men in Congo. The spread of white men in the colonies owes greatly to the existence of the Company", "the single greatest Dutch invention of them all" [13]. The stock market (hinted by the presence of men on ${ }^{\prime}$ Change $^{6}$ (men on Stock Exchange) at the beginning of the novella, enables us to see that the group of people in $H o D$ is drawn largely from the business world, which is a way of "emphasizing the fact that during the 1890s the business of empire, once an adventurous and often individualistic enterprise, had become the empire of business" [1]. In Figure 3, the connectedness between 'Company', 'Station', and 'Kurtz' shows no direct link between 'Company' and 'Kurtz'. The vital entry here seems to be 'Station', because it links 'Kurtz' and 'Company'. A close reading of the work shows that the Company is actually the vital importance that sends Marlow to Congo and connects Marlow and Kurtz.

The mapping of network fails to show that Marlow is at the heart of the story, that he is the main character whose story bears the main plot of the novella and also from whom the construction of Kurtz' mythical image is built. Marlow's connectedness to Kurtz has at least four intermediaries: 'The Swede', 'a white man', 'chief accountant', and 'the manager', all of which build Marlow's perception on Kurtz [2]. Human interconnectedness requires six degrees of separation at most [6],[15]. In $H o D$, the four degrees of separation between Marlow and Kurtz also depends upon other in-between intermediaries. As a network novel, HoD can be said to also produce "a different kind of leading "edge" that aestheticizes immanent interconnectedness" [7]. Connectedness between Marlow and Kurtz is an example of how network processes "involve different kinds of relational ties [...] and multiple types of tie" [16]. The network shown in Figure 3 is modular in nature. A network is modular if "it could be broken up into a number of separate clusters nonetheless tied together by a few bridging edges" [6]. In Figure 4 below, a modular network is the one on the bottom right:

\footnotetext{
${ }^{5}$ In 1602, at the instigation of the Dutch government, the various companies came together to form the United Dutch East India Chartered Company (Vereenigde Oostindische Compagnie/VOC), the world's very first multinational Company. In 1609, Dirk Bas and his fellow Directors declared that any share holders who wanted their cash back could not have it refunded, but would have to sell their shares to another inverstor. A market for the Company's share was thus born; it was the world's first true stock market [13].

${ }^{6}$ The term 'on 'Change' is also present in MaxHavelaar, addressing yet another idea that the practice of imperialism and colonialism is fuelled by the Company [14].
} 


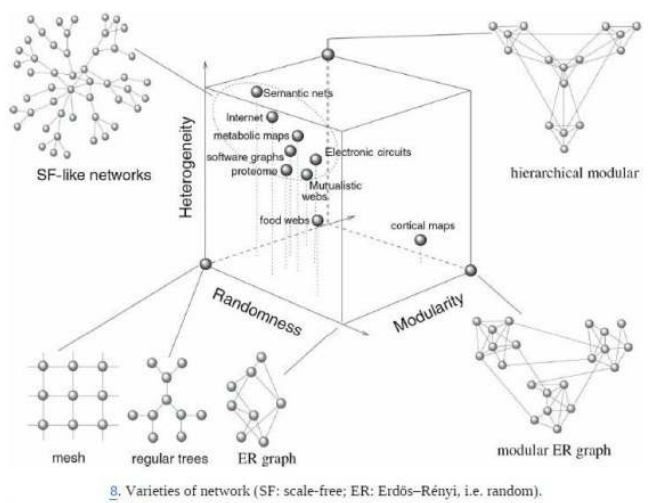

Figure 4 Types of Network [6]

A close reading of $H o D$ would have resulted to an additional imaginary line between the main cluster and the three minor clusters in Figure 3. Even by inserting entries relating to Marlow, namely 'the Swede', 'manager', and 'white man', the tools fails to identify the bridge they create that links Marlow to Kurtz.

\section{Conclusion}

In March to April of last year (2018), the world's social network giant, Facebook, was under scrutiny for its involvement in the Cambridge Analytica scandal. As a platform company, Facebook "is like the railroads," it works as a new type of infrastructure that "connect[s] people and transform society, politics, the nature of time and space itself" [17]. In reaction to this, network analysis is therefore highly relevant in today's world. Ferguson (2017) proposes seven insights of network theory, one of which states "No man is an island", meaning that individuals - as nodes in networks - can be understood in terms of their relationships to other nodes: the edges that connect them. Furthermore, network theory also shows that "not all nodes are equal", and "an individual can be assessed in terms not only of degree centrality (the number of her relationships), but also of betweenness centrality (the likelihood of her being a bridge between other nodes)" [6]. In the network text analysis conducted, "betweenness centrality" in Marlow and Kurtz is overlooked. This goes to show that network analyzers only helps to provide a short cut to surface reading. A text as complex as $H o D$, which demontrastes Conrad's genius [18],[19],[20],[21] in narrative technique as critiques towards imperialism [1],[22],[23], most definitely requires a close reading; the very mode of reading that can only be done manually. In a world where a revolutionary AI system that can write news stories and works of fiction (dubbed "deepfakes for text") [24] has been created, challenges in using advanced technology could potentially give birth to automated and machinic life. But, as shown in this essay, it seems like the future still needs to count on manual mode of doing. 


\section{References}

[1] E. W. Said, "Two Visions in Heart of Darkness," in Bloom's Modern Critical Interpretations: Joseph Conrad's Heart of Darkness-New Edition, Harold Bloom (Ed.), U.S.A.: Infobase Publishing, pp. 5-18, 2008.

[2] J. Conrad, Heart of Darkness, New York: Dell Publishing Co., Inc., 1960.

[3] S. Hunter and S. Smith, "A Network Text Analysis of Conrad's Heart of Darkness," in English Linguistics Research, vol. 3, no. 2, pp.39-53, 2014.

[4] Voyant Tools. (2019, March)[Online]. Available: https://voyant-tools.org/

[5] Cytoscape. (2019, March)[Online]. Available: https://cytoscape.org/

[6] N. Ferguson, The Square and the Tower: Networks, Hierarchies, and the Struggle for Global Power, Great Britain: Penguin, 2017.

[7] P. Jagoda, Network Aesthetics, Chicago and London: The University of Chicago Press, 2016.

[8] U. Brandes and T. Erlebach, Network Analysis: Methodological Foundations, Germany: Springer, 2005.

[9] N. Baumann and S. Stiller, "Network Models," in Network Analysis: Methodological Foundations, Ulrik Brandes and Thomas Erlebach (Eds.), Germany: Springer, pp. 341372, 2005.

[10] P. V. Marsden, "Recent Developments in Network Measurement," in Models and Methods in Social Network Analysis. Peter J. Carrington, John Scott, and Stanley Wasserman (Eds.), Cambridge: Cambridge University Press, pp. 8-30, 2005.

[11] D. Koschützki, K. A. Lehmann, L. Peeters, S. Richter, D. Tenfelde-Podehl, and O. Zlotowski, "Centrality Indices," in Network Analysis: Methodological Foundations, Ulrik Brandes and Thimas Erlebach (Eds.), Germany: Springer, pp. 16-61, 2005.

[12] S. Wasserman, J. Scott, and P. J. Carrington, "Introduction,", in Models and Methods in Social Network Analysis, Peter J. Carrington, John Scott, and Stanley Wasserman, Cambridge: Cambridge University Press, pp. 1-7, 2005.

[13] N. Ferguson, The Ascent of Money: A Financial History of the World [Documentary DVD]. Britain: Channel 4, 2009.

[14] Multatuli, Max Havelaar or the Coffee Auctions of the Dutch Trading Company, Baron Alphonse Nahuÿs (Trans.), Edmonston \& Douglas: Edinburgh, 1868.

[15] A. J. Adipurwawidjana, "Naipaul dan Jarak Tekstual: "Six Degrees of Naipaul's Separation from Our Material Reality"," in Kalam, vol. 20, pp.167-184, 2003.

[16] L. M. Koehly and P. Pattison, "Random Graph Models for Social Networks: Multiple Relations or Multiple Raters," in Models and Methods in Social Network Analysis. Peter J. Carrington, John Scott, and Stanley Wasserman (Eds.), Cambridge: Cambridge University Press, pp. 162-191, 2005.

[17] P. Blumenthal. (2018, April) The problem with facebook is no one can agree on a metaphor. [Online]. Available: https://www.huffpost.com/entry/facebookregulation-railroads n $5 \mathrm{ad} 0 \mathrm{f} 6 \mathrm{c} 0 \mathrm{e} 4 \mathrm{~b} 077 \mathrm{c} 89 \mathrm{ce} 8601 \mathrm{f}$

[18] H. Clifford. "The Genius of Mr. Joseph Conrad," in The North American Review, vol. 178, no. 571, pp. 842-852, 1904.

[19] J. Huneker, "The Genius of Joseph Conrad," in The North American Review, vol. 200, no. 705, pp. 270-279, 1914.

[20] J. M. Robertson, "The Novels of Joseph Conrad," in The North American Review, vol. 208, no.754 (Sep., 1918), pp. 439-453, 1918. 
[21] J. H. Clarke, "Joseph Conrad and His Art," in The Sewanee Review, vol. 3, no. 3, pp. 258$276,1922$.

[22] C. Watts, "'Heart of Darkness," in The Cambridge Companion to Joseph Conrad. J. H. Stape (Ed.), Cambridge: Cambridge University Press, 1996.

[23] M. Greaney, Conrad, Language, and Narrative, Cambridge: Cambridge University Press, 2004.

[24] A.Hern. (2019, Feb.) New AI fake text generator may be too dangerous to release, say creators. [Online]. Available: https://www.theguardian.com/technology/2019/feb/14/elon-musk-backed-ai-writesconvincing-news-fiction 